\title{
STUDI MUTU BRIKET ARANG DENGAN BAHAN BAKU LIMBAH BIOMASSA
}

\author{
Renny Eka Putri dan Andasuryani \\ Jurusan Teknik Pertanian Fakultas Teknologi Pertanian Universitas Andalas, \\ Kampus Limau Manis-Padang 25163 \\ Email: renny.ekaputri@yahoo.co.id
}

\begin{abstract}
ABSTRAK
Briket tempurung kelapa merupakan salah satu sumber energi alternatif yang berasal dari limbah biomassa, sehingga dapat mengurangi ketergantungan pada energi fosil. Tujuan dari penelitian ini yaitu mengevaluasi mutu briket arang tempurung kelapa yang dihasilkan dan uji teknis alat kempa briket yang digunakan. Hasil pengujian menunjukkan bahwa kapasitas alat kempa yang digunakan adalah 302 batang briket/jam. Briket yang dihasilkan mempunyai kadar air sebesar 5,37 \%. Kadar air briket sudah sesuai dengan SNI yaitu $\leq 8 \%$. Densitas briket rata-rata adalah $11,23 \mathrm{~g} / \mathrm{cm}^{3}$. Nilai kuat tekan maksimum adalah sebesar $1.4 \mathrm{~N} / \mathrm{m}^{2}$. Nilai kadar karbon mencapai $97.14 \%$. Hal ini menunjukkan briket yang dihasilkan berkualitas karena nilai kadar karbon yang tinggi dan kadar abu nya yang rendah. Nilai kalor yang dihasilkan juga sangat tinggi ( $\geq 5000$ ) yang membuktikan bahwa kualitas briket yang dihasilkan sangat tinggi, sehingga briket tempurung kelapa ini dapat dijadikan energy alternative oleh masyarakat Sumatra Barat khususnya.

Kata kunci-Biomassa; Tempurung Kelapa; Briket Arang.
\end{abstract}

\section{PENDAHULUAN}

Sumber energi alternatif yang dapat diperbaharui di Indonesia cukup banyak, diantaranya adalah biomassa atau bahan-bahan limbah organik. Beberapa biomassa memiliki potensi yang cukup besar adalah limbah kayu, sekam padi, jerami, ampas tebu, tempurung kelapa, cangkang sawit, kotoran ternak dan sampah kota. Biomassa dapat diolah dan dijadikan sebagai bahan bakar alternatif, contohnya dengan pembuatan briket. Bahan bakar yang biasa digunakan oleh masyarakat di daerah Nahari Aie Tajun adalah minyak tanah untuk keperluan rumah tangga. Padahal ketersediaan akan minyak tanah itu sendiri sudah semakin langka. Solusinya, pemerintah Indonesia telah mengeluarkan beberapa kebijakan energi untuk mengurangi ketergantungan akan energi minyak bumi dan menggunakan kompor berbahan bakar gas sebagai pengganti minyak tanah. Namun, dalam pelaksanaan kebijakan ini masyarakat masih merasa terbebani karena harga gas yang juga cukup mahal. Oleh karena itu, dibutuhkan energi alternatif yang dapat diperbaharui, murah dan mudah didapatkan sebagai bahan bakar untuk keperluan rumah tangga.

Nagari Aia Tajun Kecamatan Lubuk Alung Kabupaten Padang Pariaman memiliki banyak sumber energi alternatif yang dapat diperbaharui seperti biomassa atau bahan dari limbah organik. Ada beberapa limbah biomassa yang dapat dimanfaatkan seperti limbah kayu, sekam padi, ampas tebu, tempurung kelapa, kulit kakao, kotoran ternak dan sampah kota lainnya. Biomassa merupakan sumber energi utama ketiga terbesar di dunia, setelah minyak dan batubara. Oleh karena itu, pemanfaatan biomassa sebagai bahan bakar alternatif pengganti bahan bakar fosil merupakan salah satu pilihan pengembangan mekanisme bersih (clean development mechanism, $\mathrm{CDM}$ ) untuk mengurangi emisi karbon ke atmosfer. Limbah pertanian dapat menghasilkan energi kalor sekitar $6000 \mathrm{kal} / \mathrm{g}$. Limbah pertanian yang terdiri dari sekam memiliki kadar karbon $1,33 \%$, jerami mempunyai kadar karbon 2,71 $\%$, dan tempurung kelapa memilik kadar karbon yang tinggi sebesar 18,80 \% (Pancapalaga, 2008). Tujuan dari penelitian yaitu mengevaluasi teknis alat kempa briket yang diguanakan dan menganalisis mutu briket arang tempurung kelapa sebagai bahan bakar alternatif sesuai SNI.

\section{METODOLOGI PENELITIAN}

\section{A. Alat dan Bahan}

Penelitian ini dilakukan di Nagari Aie Tajun Lubuk Alung Kabupaten Padang Pariaman, sedangkan Alat kempa yang digunakan untuk pencetakan dibuat di Bengkel Program Studi Teknik Pertanian Universitas Andalas. Alat yang digunakan adalah kaleng cat, tungku, drum, seng, ayakan, 
timbangan manual, alat pengempa dan pencetak briket, lesung, dan stopwatch. Bahan-bahan yang digunakan adalah tempurung kelapa, tepung kanji dan air. Penelitian ini menggunakan komposisi dari bahan baku arang tempurung kelapa, yang bertujuan untuk mendapatkan nilai kalor yang tinggi dari briket arang tempurung kelapa. Dalam pelaksanaan penelitian ini terdiri dari 3 tahap, yaitu tahap pembuatan alat pencetak briket, tahap pembatan briket dan tahap pengujian briket.

\section{Pembuatan Alat Kempa Briket}

Alat pencetak briket ini dibuat di bengkel Program Studi Teknik Pertanian Fakultas Teknologi Pertanian Universitas Andalas dengan tinggi silinder $4 \mathrm{~cm}$ dan diameter silinder $2 \mathrm{~cm}$. Alat kempa terdiri dari beberapa bagian sebagai berikut :

a. Dongkrak, untuk memberikan gaya ke bawah agar pengepress menyentuh silinder yang berisi adonan briket yang akan dicetak.

b. Kaki/penyangga, untuk menyangga alat pengempa briket selama pengoperasian berlangsung.

c. Alat pencetak, untuk mengepress briket agar briket tercetak kandungan air nya keluar.

d. Silinder, sebagai wadah untuk menginput briket agar briket tercetak sesuai dengan bentuk nya.

e. Tuas, untuk mengeluarkan hasil cetakan briket.

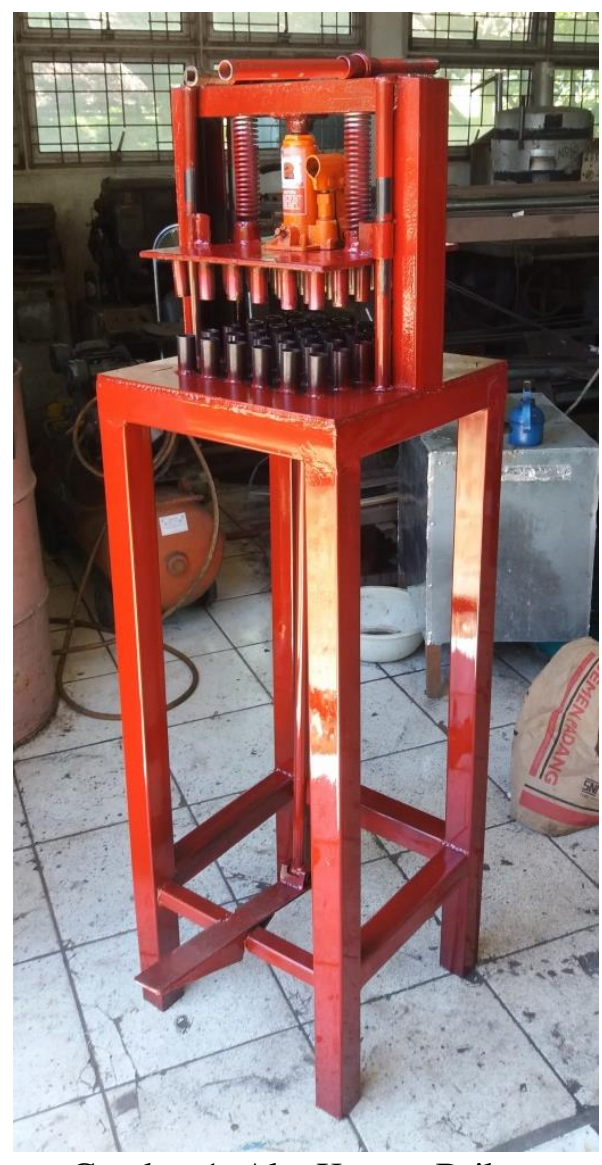

Gambar 1. Alat Kempa Briket

\section{Persiapan Pembuatan Briket}

\section{a. Penyiapan Bahan Baku Briket}

Bahan baku yang disiapkan adalah tempurung kelapa yang sudah kering. Penggunaan tempurung kelapa yang sudah kering dapat mempercepat proses pengarangan dibandingkan tempurung kelapa yang masih basah. Hal ini dikarenakan kadar air pada tempurung kelapa yang sudah kering lebih sedikit. Sebelum dilakukan pengarangan, tempurung kelapa dihancurkan menjadi ukuran yang lebih kecil. Hal ini bertujuan agar mempercepat proses pengarangan, mudah dihaluskan, dan menghasilkan volume pengarangan yang lebih banyak di dalam kaleng cat. 


\section{b. Pengarangan}

Proses pengarangan dilakukan secara bersamaan dengan dua kaleng cat bekas menggunakan dua metode yang berbeda. Hal ini dilakukan untuk mengetahui apakah terdapat perbedaan kuantitas maupun kualitas hasil yang diperoleh. Metode pertama, api dinyalakan didalam kaleng cat yang berisi tempurung kelapa. Metode kedua, dibuat tungku api, kemudian tempurung kelapa yang sudah dihancurkan dimasukkan ke dalam kaleng cat yang diletakkan di atas tungku dalam keadaan tertutup, namun diberi celah untuk masuknya sedikit oksigen. Proses pengarangan dihentikan apabila tempurung kelapa sudah berubah warna seutuhnya menjadi arang hitam.

\section{c. Penggilingan Arang}

Bara arang yang telah jadi dituangkan di atas permukaan plat, kemudian bara dibiarkan hingga asap dan panas menghilang. Selanjutnya, arang dihaluskan dengan penggiling sampai halus dan diayak agar mendapatkan ukuran serbuk yang sangat halus.

\section{d. Persiapan Perekat}

Perekat tepung kanji ditimbang sebanyak $10 \%$ dari berat bahan baku per satuan briket. Penggunaan tepung kanji harus dalam kadar yang sesuai agar mendapatkan mutu briket dan api yang bagus. Menurut Triono (2006), kadar perekat dalam briket arang tidak boleh terlalu tinggi karena dapat mengakibatkan penurunan mutu briket arang yang sering menimbulkan banyak asap. Kadar perekat yang digunakan umumnya tidak lebih dari 5\%. Kemudian perekat dicampur dengan air perbandingan konsentrsi perekat dan air 1 : 20. Proses pembuatannya yaitu dengan mencampurkan tepung kanji dengan air panas lalu diaduk hingga homogen. Kemudian perekat tersebut dicampurkan dan diadon dengan serbuk arang.

\section{e. Pembuatan Adonan Briket}

Arang tempurung kelapa yang telah diayak kemudian dibuat adonan briket setelah terlebih dahulu dicampur dengan perekat tepung kanji sebanyak $10 \%$ dari berat bahan baku per satuan briket. Serbuk arang tempurung kelapa dan perekat diaduk sampai rata hingga adonan siap untuk dicetak.

\section{f. Pencetakan dan Pengempaan}

Pencetakan adonan briket dilakukan saat adonan briket sudah menggumpal dan adukan telah homogen. Bentuk briket hasil cetakan adalah berbentuk silinder dengan ukuran diameter $2 \mathrm{~cm}$ dan tinggi $4 \mathrm{~cm}$. Caranya adalah dengan memasukkan adonan briket kedalam silinder cetakan, kemudian dikempa dengan alat pengepres briket dengan tekanan yang besar hingga padat. Setelah itu, pengunci dibuka agar pengempa terlepas dari silinder dan cetakan siap untuk dikeluarkan.

\section{g. Pengeringan}

Pengeringan dilakukan dengan cara dijemur di bawah sinar matahari langsung selama beberapa hari. Hal ini bertujuan agar didapatkan kadar air sesuai SNI yaitu 8\%. Sehingga ketika briket dinyalakan, didapatkan api yang bagus, cepat menyala dan tidak berasap.

\section{Tahap Pengujian}

\section{a. Pengujian Alat}

Pengujian alat dilakukan untuk mengamati waktu yang dihabiskan untuk proses pengempaan sampai bahan dapat dikeluarkan dari alat kempa. Pengamatan dilakukan dengan cara menginput adonan ke dalam 36 silinder yang terdapat pada alat pengempa hingga memadat. Lalu adonan yang telah dimasukkan tersebut dikempa hingga kedalaman $1 \mathrm{~cm}$. Setelah itu pengunci dilepas sehingga menyebabkan silinder terpisah dengan pengempa bagian atas. Selanjutnya dongkrak ditekan ke belakang untuk mengeluarkan hasil briket yang telah dicetak.

\section{b. Pengamatan penelitian}

\section{1) Kapasitas Pengempaan}

Kapasitas pengempaan adalah kemampuan alat kempa untuk mencetak briket dalam satuan waktu (unit/jam). Waktu yang diukur adalah total waktu dari memasukkan bahan ke selinder pencetak sampai mengeluarkan hasil cetakan. 


\section{2) Kadar air}

Kadar air sampel ditentukan dengan metode oven, dengan cara menimbang bahan dengan timbangan analisis $5 \mathrm{~g}$ dalam cawan alumunium yang telah diukur bobot keringnya. Kemudian dikeringkan didalam oven pada suhu $105{ }^{\circ} \mathrm{C}$ sampai beratnya konstan, kemudian bahan didinginkan didalam desikator dan timbang kembali. Penentuan kadar air dilakukan sebanyak lima kali pengulangan. Perhitungan kadar air :

$\%$ Kadar air $=\frac{b-c}{b-a} \times 100 \%$

Keterangan :

$\mathrm{a}=$ berat cawan kosong $(\mathrm{g})$

$\mathrm{b}=$ berat cawan + sampel briket $(\mathrm{g})$

$\mathrm{c}=$ berat cawan + sampel briket setelah di oven hingga beratnya konstan $(\mathrm{g})$

\section{3) Kerapatan massa (densitas)}

Kerapatan massa briket setelah dikempa dapat dicari dengan cara mengukur massa sampel briket yang kemudian dibagi dengan volume sampel briket tersebut. Densitas briket dapat dinyatakan dengan rumus :

$\rho=\frac{M}{V}$

Keterangan :

$$
\begin{aligned}
& \rho=\text { Kerapatan }\left(\mathrm{g} / \mathrm{cm}^{3}\right) \\
& \mathrm{M}=\operatorname{Massa}(\mathrm{g}) \\
& \mathrm{V}=\pi \times \mathrm{r} \mathrm{r}^{2} \times \mathrm{t}=\text { Volume silinder }\left(\mathrm{cm}^{3}\right)
\end{aligned}
$$

\section{4) Kekuatan tekan mekanik pada briket}

Pengukuran kuat tekan mekanik dilakukan dengan menggunakan alat Force gauge. Pengujian kuat tekan dapat dihitung dengan :

$\tau=\frac{P}{A}$.......

Keterangan :

$\tau=$ kuat tekan $\left(\mathrm{N} / \mathrm{mm}^{2}\right)$

$\mathrm{P}=$ beban maksimum $(\mathrm{N})$

$\mathrm{A}=$ luas penampang melintang $\left(\mathrm{mm}^{2}\right)$

\section{5) Kadar abu}

Dalam pengujian ini sampel ditimbang 5 gram dan dimasukkan kedalam cawan porselen, sampel dipanaskan sampai menjadi arang dan tidak mengeluarkan asap. Kemudian diabukan dalam tanur pada suhu $60{ }^{\circ} \mathrm{C}$ hingga menjadi abu, didinginkan di dalam desikator kemudian segera timbang setelah mencapai suhu ruang. Penentuan kadar abu dilakukan sebanyak lima kali pengulangan.

Perhitungan :

$\%$ kadar abu $=\frac{\text { berat abu }}{\text { Berat sampel }} \times 100 \%$

\section{6) Laju Pembakaran Briket}

Laju pembakaran briket dihitung dengan cara berat briket yang telah dinyalakan dibagi dengan waktu pembakaran sampai briket habis terbakar atau menjadi abu.

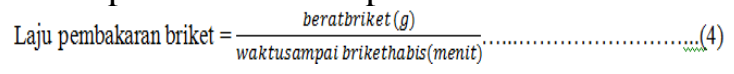

\section{7) Nilai kalor}

Kalor merupakan suatu kuantitas atau jumlah panas yang baik yang diserap maupun dilepaskan oleh suatu benda. Nilai kalor diperoleh dari briket dengan data laboratorium. Prosedur kerja untuk menentukan nilai kalor yaitu:

a. Sampel dihancurkan dan ditimbang, kemudian dimasukkan kedalam cawan pembakar tepat dibawah lengkungan kawat sumbu yang kedua ujungnya telah dikaitkan pada kedua elektroda. 
b. Rangkaian tersebut kemudian dimasukkan kedalam bomb yang sebelumnya telah diisi akuades sebanyak $1 \mathrm{ml}$ kedalam bomb, selanjutnya ditutup rapat dan dialiri gas oksigen melalui katup kurang lebih $35 \mathrm{~atm}$. Bomb dimasukkan kedalam kalorimeter yang telah diisi air sebanyak 2 liter, dan dihubungkan dengan unit pembakar.

c. Kalorimeter (alat yang digunakan untuk mengukur jumlah kalor yang terlibat dalam suatu perubahan atau reaksi kimia ) ditutup dan termometer dipasang pada tutup kalorimeter, sehingga skala pada bagian bawah tepat pada angka $19^{\circ} \mathrm{C}$, temperatur konstan pengaduk listrik dihidupkan dan dibiarkan selama 5 menit, kemudian sumber tegangan arus 23 volt dihidupkan untuk membakar kawat sumbu. Pada saat ini temperatur diamati maka temperaturakan naik dengan cepat, setelah itu konstan dan akhirnya sedikit akan turun, kemudian sumber tegangan pembakar dan pengaduk dimatikan.

d. Rumus penghitungan nilai kalor :

Nilai kalor $=\{(\mathrm{T} 2-\mathrm{T} 1)-0,05\}$

Keterangan :

$\mathrm{T} 1=$ Temperatur sebelum pengeboman $\left({ }^{\circ} \mathrm{C}\right)$

$\mathrm{T} 2=$ Temperatur setelah pengeboman $\left({ }^{\circ} \mathrm{C}\right)$

$\mathrm{Cv}=$ Panas jenis Bomb Calorimeter $\left(73529,6\right.$ joule $\left./ \mathrm{g}^{\circ} \mathrm{C}\right)$

\section{HASIL DAN PEMBAHASAN}

\section{A. Kapasitas Pengempaan}

Waktu pengempaan pada pengamatan ini dibagi menjadi tiga bagian yaitu waktu input bahan ke luang kempa, waktu pengempaan dan waktu mengeluarkan bahan dari alat kempa. Tabel 1 memperlihatkan waktu yang dibutuhkan untuk menghasilkan 36 selinder briket. Waktu paling banyak dibutuhkan adalah saat pengisian bahan pada lubang-lubang kempa, sedangkan pengempaan hanya membutuhkan waktu 29-46 detik. Waktu yang dibutuhkan untuk mengeluarkan dari alat kempa sekitar 59-73 detik. Total waktu untuk mengempa 36 selinder briket membutuhkan total waktu 429 detik, maka kapasitas pengempaan adalah 302 selinder/jam. Dalam waktu satu jam dapat menhasilkan 302 batang arang briket.

Tabel 1. Tahap Pengujian Alat Briket

\begin{tabular}{cccc}
\hline Pengulangan & Lama Input (detik) & $\begin{array}{c}\text { Lama Kempa } \\
(\text { detik) }\end{array}$ & Lama Output (detik) \\
\cline { 2 - 4 } & 425 & 35 & 73 \\
2 & 306 & 32 & 64 \\
3 & 272 & 46 & 61 \\
4 & 337 & 29 & 71 \\
5 & 304 & 32 & 59 \\
\hline
\end{tabular}

\section{B. Kadar Air}

Briket arang memiliki sifat higroskopis (mudah menyerap air dari sekelilingnya) yang tinggi. Penghitungan kadar air bertujuan untuk mengetahui sifat higroskopis briket arang hasil penelitian. Pengukuran kadar air briket arang dilakukan setelah dikempa dan dikeringkan dengan nilai rata-rata kadar air dibawah SNI yaitu 8\%. Nilai rata-rata kadar air briket arang dapat dilihat pada Tabel 3. Berdasarkan Tabel 3 terlihat bahwa nilai rata-rata kadar air awal briket terendah adalah 5,37 \%. Hal ini sesuai dengan pernyataan Triono (2006) tingginya kadar air disebabkan karena jumlah pori-pori yang lebih banyak. Kadar air sangat berpengaruh terhadap kualitas briket yang dihasilkan, semakin rendah kadar air briket maka akan semakin tinggi nilai kalor dan daya pembakarannya. Kadar air yang tinggi akan membuat briket sulit dinyalakan pada saat pembakaran dan akan banyak menghasilkan asap, selain itu akan mengurangi temperatur penyalaan dan daya pembakarannya (Hutasoit, 2012). 


\section{Densitas}

Tabel 3. Rata-rata Kadar Air Briket

\begin{tabular}{cc}
\hline Sampel & Kadar air $(\%)$ \\
\hline 1 & 4.48 \\
2 & 6.52 \\
3 & 5.875 \\
4 & 4.6 \\
Rata-rata & 5.369 \\
\hline
\end{tabular}

Densitas merupakan perbandingan antara berat dengan volume briket. Besar kecilnya kerapatan dipengaruhi oleh ukuran dan kehomogenan penyusun briket tersebut. Nilai rata-rata densitas masingmasing komposisi briket dapat dilihat pada Tabel 4. Berdasarkan Tabel 4 terlihat bahwa nilai kerapatan tertinggi sebesar $13.847 \mathrm{~g} / \mathrm{cm}^{3}$, sedangkan nilai kerapatan terendah yaitu $9.41 \mathrm{~g} / \mathrm{cm}^{3}$. Densitas yang tinggi disebabkan karena ikatan antar bubuk arang tempurung kelapa lebih padu dan kuat serta tekstur tempurung kelapa yang keras. Ukuran partikel yang lebih kecil dapat memperluas bidang ikatan antar serbuk, sehingga dapat meningkatkan kerapatan briket (Masturin, 2002).

Tabel 4. Nilai Rata-rata Densitas Briket

\begin{tabular}{cc}
\hline Sampel & Densitas $\left(\mathrm{g} / \mathrm{cm}^{3}\right)$ \\
\hline 1 & 11.932 \\
2 & 9.776 \\
3 & 9.41 \\
4 & 13.847 \\
Rata-rata & 11.241 \\
\hline
\end{tabular}

\section{Kuat Tekan Briket}

Uji kuat tekan dilakukan untuk mengetahui kekuatan briket dalam menahan beban dengan tekanan tertentu. Tingkat kekuatan tersebut diketahui ketika briket tidak mampu menahan beban lagi. Berdasarkan hasil pengamatan dan perhitungan yang dilakukan terhadap nilai rata-rata kekerasan briket pada masing-masing sampel dapat dilihat pada Tabel 5. Berdasarkan Tabel 5 terlihat bahwa nilai kuat tekan tertinggi sebesar $1.4 \mathrm{~N} / \mathrm{m}^{2}$ dan nilai kuat tekan terendah sebesar $0.4 \mathrm{~N} / \mathrm{m}^{2}$. Penggunaan tempurung kelapa dalam kadar yang tinggi dapat mempengaruhi nilai kekerasan briket. Hal tersebut karena tempurung kelapa memiliki kerapatan partikel lebih besar, sehingga semakin tinggi kandungan tempurung kelapa dalam komposisi briket maka akan meningkatkan nilai kekerasan briket yang dihasilkan. Menurut Triono (2006), semakin tinggi nilai kuat tekan briket, maka daya tahan briket semakin baik.

Tabel 5. Rata-rata Nilai Kuat Tekan Briket

\begin{tabular}{cc}
\hline Sampel & Kuat Tekan $\left(\mathrm{N} / \mathrm{m}^{2}\right)$ \\
\hline 1 & 0.4 \\
2 & 0.4 \\
4 & 0.5 \\
Rata-rata & 1.4 \\
\hline
\end{tabular}

\section{E. Kadar Abu}

Kadar abu merupakan bagian yang tersisa dari hasil pembakaran, dalam hal ini abu yang dimaksud adalah abu sisa pembakaran briket. Salah satu penyusun abu adalah silika, pengaruhnya kurang baik terhadap nilai kalor briket arang yang dihasilkan. Kadar abu briket berpengaruh terhadap nilai kalor dan nilai kadar karbon. Semakin kecil nilai kadar abu maka semakin tinggi nilai kalor dan kadar karbonnya. Nilai kadar abu briket pada setiap sampel dapat dilihat pada Tabel 6. Berdasarkan Tabel 6 terlihat bahwa nilai kadar abu rata-rata adalah sebesar $4.11 \%$. 
Tabel 6. Rata-rata Nilai Kadar Abu Briket

\begin{tabular}{cc}
\hline Sampel & Kadar Abu (\%) \\
\hline 1 & 5.67 \\
2 & 2.86 \\
3 & 3.80 \\
Rata-rata & 4.11 \\
\hline
\end{tabular}

\section{F. Kadar Karbon}

Kadar karbon terikat (fixed carbon) merupakan fraksi karbon (C) yang terikat di dalam briket selain fraksi abu, air, dan zat menguap. Kadar karbon akan bernilai tinggi apabila kadar abu dan kadar zat menguap briket rendah. Selain itu, nilai kadar air yang rendah akan meningkatkan nilai kadar karbon. Kadar karbon briket berpengaruh terhadap nilai kalor. Semakin besar nilai kadar karbon maka semakin tinggi nilai kalornya. Kadar karbon yang tinggi pada briket akan menghasilkan briket berkualitas baik. Berdasarkan hasil pengamatan dan perhitungan yang dilakukan, maka nilai kadar karbon dapat dilihat seperti pada Tabel 7.

Tabel 7. Rata-rata Nilai Kadar Karbon

\begin{tabular}{cc}
\hline Sampel & Kadar Karbon $(\%)$ \\
\hline 1 & 94.33 \\
2 & 97.14 \\
3 & 96.20 \\
Rata-rata & 95.89 \\
\hline
\end{tabular}

Berdasarkan Tabel 7 dapat dilihat bahwa nilai kadar karbon tertinggi terdapat pada sebesar 97.14 $\%$, dan nilai kadar karbon terkecil sebesar $94.33 \%$. Menurut Rustini (2004) bahwa kadar karbon di dalam briket arang dipengaruhi oleh nilai kadar abu, semakin rendah nilai kadar abu briket arang maka nilai kadar karbon terikatnya akan semakin tinggi. Hal ini sesuai dengan penelitian yang telah dilakukan bahwa perlakuan yang memiliki nilai kadar abu rendah maka akan menghasilkan nilai kadar karbon yang tinggi begitu juga sebaliknya.

\section{G. Nilai Kalor}

Nilai kalor sangat menentukan kualitas briket. Semakin tinggi nilai kalor, maka semakin baik pula kualitas briket yang dihasilkan. Tinggi dan rendahnya nilai kalor pada suatu briket itu semua tergantung pada nilai kadar air, kadar abu, dan kadar karbonnya. Nilai kalor yang dihasilkan pada masing-masing sampel dapat dilihat pada Tabel 8. Berdasarkan Tabel 8 terlihat bahwa nilai kalor tertinggi sebesar $6401.64 \mathrm{kal} / \mathrm{g}$, sedangkan nilai kalor terendah yaitu $5946.83 \mathrm{kal} / \mathrm{g}$. Hal ini karena nilai kalor briket dipegaruhi oleh kadar abu briket dan kadar karbon. Semakin tinggi kadar karbon maka nilai kalor briket yang dihasilkan akan semakin tinggi begitu juga sebaliknya, semakin rendah kadar karbon maka nilai kalor yang dihasilkan semakin rendah karena di dalam proses pembakaran membutuhkan karbon yang bereaksi dengan oksigen untuk menghasilkan kalor.

Tabel 8. Rata-rata Nilai Kalor

\begin{tabular}{cc}
\hline Sampel & Nilai Kalor (kalori/g) \\
1 & 6132.67 \\
2 & 5946.83 \\
3 & 6401.64 \\
Rata-rata & 6160.38 \\
\hline
\end{tabular}

\section{H. Nyala Api untuk Memanaskan Air}

Uji nyala api untuk memanaskan air 1 liter hingga mendidih dilakukan untuk mengetahui lama waktu briket habis sampai menjadi abu. Pengamatan menggunakan briket sebanyak 80 g. Berdasarkan hasil pengamatan yang dilakukan terhadap nyala api dapat dilihat pada Tabel 9. Berdasarkan Tabel 9 
terlihat bahwa nilai nyala api tertinggi terdapat pada pengulangan 3 yaitu briket arang tempurung kelapa sebesar 358 detik, sedangkan nilai nyala api terendah 330 detik terlihat pada pengulangan 2 .

Tabel 9. Rata-Rata Nyala Api Briket

\begin{tabular}{cc}
\hline Pengulangan & Nyala Api (detik) \\
\hline 1 & 337 \\
2 & 330 \\
3 & 358 \\
Rata-rata & 341.667 \\
\hline
\end{tabular}

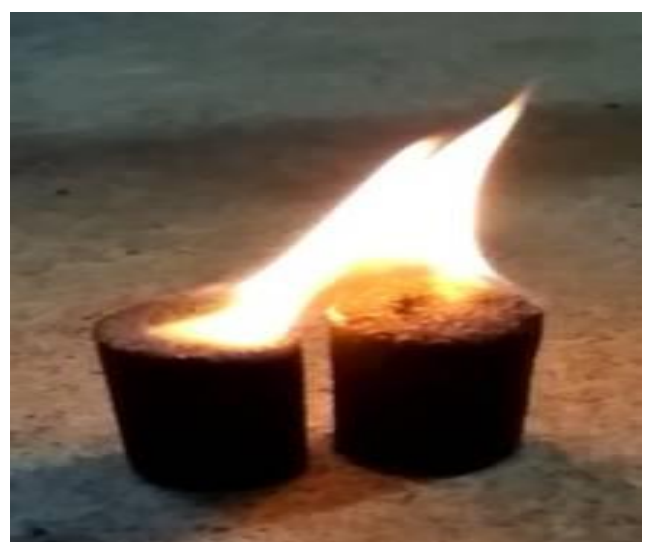

Gambar 2. Hasil Pembakaran Briket Arang

\section{Laju Pembakaran}

Laju pembakaran briket adalah kecepatan briket habis sampai menjadi abu dengan berat $80 \mathrm{~g}$. Laju pembakaran briket dipengaruhi oleh faktor nilai kalor dan kadar air. Rata-rata laju pembakaran dapat dilihat pada Tabel 10. Berdasarkan Tabel 10 terlihat bahwa nilai rata-rata laju pembakaran adalah sebesar $0,224 \mathrm{~g} /$ detik.

Tabel 10. Rata-rata Laju Pembakaran

\begin{tabular}{cc}
\hline Pengulangan & Laju Pembakaran Briket (g/detik) \\
\hline 1 & 0.237 \\
2 & 0.242 \\
3 & 0.223 \\
Rata-rata & 0.234 \\
\hline
\end{tabular}

\section{J. Mutu Briket Berdasarkan SNI}

Berdasarkan penelitian yang telah dilakukan,maka perbandingan mutu briket hasil penelitian berdasarkan SNI dapat dilihat pada Tabel 11. Berdasarkan Tabel 11 dapat dilihat bahwa jika dibandingkan dengan briket SNI maka beberapa sifat kimia briket pada penelitian ini sangat termasuk ke dalam standard tersebut. Kadar air pada briket semua sampel mencapai $\leq 8$. Kadar abu yang sesuai SNI terdapat pada semua sampel, dan kadar karbon dari semua sampel sesuai SNI. 
Tabel 11. Perbandingan Mutu Briket Hasil Penelitian Berdasarkan SNI

\begin{tabular}{|c|c|c|c|}
\hline Parameter & $\begin{array}{c}\text { SNI } \\
\text { No.1/6235/2000 }\end{array}$ & $\begin{array}{l}\text { Hasil Pengujian } \\
\text { (Rata-rata) }\end{array}$ & Kesimpulan \\
\hline Kadar Air (\%) & $\leq 8$ & 5.625 & Semua sampel sesuai dengan SNI \\
\hline Kadar Abu (\%) & $\leq 8$ & 4.11 & Semua sampel sesuai dengan SNI \\
\hline $\begin{array}{c}\text { Kadar Karbon } \\
(\%)\end{array}$ & $\geq 77$ & 95.89 & Semua sampel sesuai dengan SNI \\
\hline $\begin{array}{l}\text { Nilai Kalor } \\
(\mathrm{kal} / \mathrm{g})\end{array}$ & $\geq 5000$ & 6160.38 & Semua sampel sesuai dengan SNI \\
\hline
\end{tabular}

\section{KESIMPULAN}

Berdasarkan hasil penelitian yang dilakukan dapat disimpulkan bahwa semua briket yang dihasilkan sangat sesuai dengan SNI, karena sifat karakteristiknya sangat mendekati nilai parameter SNI. Hal ini terbukti dari pengujian mulai dari kadar air, kuat tekan, densitas, kadar abu, kadar karbon dan nilai kalor yang dihasilkan, sehingga dapat dikatakan briket yang dihasilkan layak pakai untuk masyarakat setempat. Bukti yang sangat menguatkan ialah nilai kadar karbon mencapai $97.14 \%$ yang dikategorikan sangat mendekati $100 \%$. Hal ini berarti kualitas pembakaran briket tersebut sangat bagus karena nilai kadar karbon sangat tinggi begitu pula dengan kadar abu nya yang sangat rendah menyatakan bahwa pembakaran briket yang dihasilkan sangat bagus.

\section{UCAPAN TERIMA KASIH}

Penulis mengucapkan terimakasih kepada Direktorat Jenderal Penguatan Riset dan Pengembangan, Kementerian Riset, Teknologi dan Pendidikan Tinggi, sesuai dengan Surat Perjanjian Pelaksanaan Hibah Pengabdian Kepada Masyarakat Nomor SPPK: 012/SP2H/PPM/DRPM/IV/2017 yang telah mendanai penelitian ini dan kepada seluruh pihak yang telah membantu terlaksananya penelitian ini.

\section{DAFTARPUSTAKA}

Hutasoit, Aripin. 2012. Briket Arang dari Pelepah Salak. [Skripsi]. Padang: Fakultas Teknologi Pertanian. Universitas Andalas.

Masturin, A. 2002. Sifat Fisik dan Kimia Briket Arang dari Campuran Arang Limbah Gergajian Kayu [Skripsi]. Bogor: Fakultas Kehutanan. Institut Pertanian Bogor.

Pancapalaga, Wehandako. 2008. Evaluasi Kotoran Sapi dan Limbah Pertanian (Kosap Plus) Sebagai Bahan Bakar Alternatif. http://esearch-report.umm.ac.id/index.php/researcreport/article/viewile/43/44 umm research report fulltext.pdf. [23 Januari 2015].

Rustini. 2004. Pembuatan Briket Arang dari Serbuk Gergajian Kayu Pinus (Pinus merkusii) dengan Penambahan Tempurung Kelapa [Skripsi]. Bogor: Fakultas Kehutanan, Institut Pertanian Bogor.

Triono, A. 2006. Karakteristik Briket Arang dari Campuran Serbuk Gergajian Kayu Afrika (Maesopsis emini Engl.) dan Sengon (Paraserianthes falcataria L.) [Skripsi]. Bogor: Departemen Hasil Hutan. Fakultas Pertanian. Institut Pertanian Bogor. 